CASE SERIES

\title{
THE USE OF HYPERBARIC OXYGEN THERAPY FOR EAR RECONSTRUCTION: A CASE SERIES
}

\author{
Marcella Tirza Tulong1, Mendy Hatibie Oley ${ }^{1,2,3^{*}}$, Maximillian Christian Oley ${ }^{1,4,5}$, Ali Sundoro 6 , \& \\ Muhammad Faruk ${ }^{7}$ \\ 1. Hyperbaric Centre Siloam Hospital, Manado, Indonesia \\ 2. Reconstructive E Aesthetic Plastic Surgery Division, Department of Surgery, Faculty of Medicine, Sam Ratulangi University, Manado, \\ Indonesia \\ 3. Reconstructive E Aesthetic Plastic Surgery Division, Department of Surgery, R. D. Kandou Hospital, Manado, Indonesia \\ 4. Division of Neurosurgery, Department of Surgery, Faculty of Medicine, Sam Ratulangi University, Manado, Indonesia \\ 5. Division of Neurosurgery, Department of Surgery, R. D. Kandou Hospital, Manado, Indonesia \\ 6. Reconstructive $\mathcal{E}$ Aesthetic Plastic Surgery Division, Department of Surgery, Faculty of Medicine, Padjajaran University, Bandung, \\ Indonesia \\ 7. Department of Surgery, Faculty of Medicine, Hasanuddin University, Makassar, Indonesia
}

\begin{abstract}
Introduction: The unique anatomy of the ear makes the reconstruction more challenging. Microtia and auricula hematomas are deformities or defects that can occur in the ear. Treating traumatic injury and congenital malformations of the ears needs some technique and expertise. Hyperbaric Oxygen Therapy is an additional therapy that makes a significant contribution and is effective in wound healing.

Case Series: In our first case, a 52-year-old man presented with a traumatic right cauliflower ear due to a traffic accident two weeks before hospital admission. The second case involves a boy 14-year-old who has a Microtia in the right ear with total ear construction performed using autologous costochondral cartilage techniques in a twostage.

Results: Both cases following hyperbaric oxygen therapy, yield good results with good scars, no sign of infection nor tissue necrosis

Summary: The combination therapy of reconstructive surgery and administration of oxygen therapy gave satisfactory results in both cases. Five sessions of hyperbaric treatment showed promising results. There is no infection, rapid wound healing, and cessation of flap compromise.

Keywords: Ear Reconstruction; Microtia; Auricula Hematoma; Hyperbaric Oxygen Therapy.
\end{abstract}

\section{ABSTRAK}

Later Belakang: Anatomi telinga yang unik menjadikan usaha rekonstruksi pada derah tersebut sulit. Microtia dan hematoma pada telinga merupakan sebuah deformitas yang umum terjadi pada telinga. Tatalaksana trauma dan malformasi kongenital pada telinga memerlukan pengangan khusus. Peran Terapi Oksigen Hiperbarik, sebagai terapi tambahan yang memberikan kontribusi signifikan dan efektif pada penyembuhan luka.

Laporan Kasus: Pada kasus pertama, laki-laki 52 tahun dengan riwayat trauma telinga dan cauliflower ear kanan karena kecelakaan lalu lintas 2 minggu sebelumnya. Kasus kedua meliputi anak 14 tahun dengan Microtia pada telinga kanan dengan rekonstruksi telinga total dengan cartilage dari costae dengan dua tahap operasi

Hasil: Kedua kasus menjalani Terapi Oksigen Hiperbarik, memberikan hasil yang baik dengan parut yang baik, tidak ada infeksi ataupun kematian jaringan

Ringkasan: Terapi kombinasi bedah rekonstruksi dan admistrasi terapi oksigen memberikan hasil yang memuaskan pada kedua kasus diatas. Sebanyak 5 kali sesi terapi emberikan hasil yang menjanjikan. Tidak ada infeksi, penyembuhan luka yang cepat dan menghindari flap yang non-vital

Kata Kunci: Rekonstruksi telinga, Microtia, Hematom Telinga, Terapi Oksigen Hiperbarik

\section{Conflicts of Interest Statement:}

The Author (s) listed in this manuscript declare the absence of any conflict of interest on the subject matter or materials discussed. 


\section{INTRODUCTION}

With a complex ear structure, the ear is one of the most complicated anatomies of the human body. The shape of the ears that protrude from the side dramatically affects the aesthetics of the face shape ${ }^{1}$. The deformity of the ear affects both physically and psychologically the patient. The ear can be deformed or defective either biologically or due to trauma ${ }^{2}$. Trauma to the ear can cause a blood collection to become trapped under the tissue. This reduces blood supply, resulting in necrosis and cartilage destruction. Improper handling can cause the auricle hematoma to reform ${ }^{3}$. To prevent this, hyperbaric therapy is needed as an additional therapy to accelerate wound healing and prevent complications such as infection and tissue necrosis.

Microtia and auricular hematomas are deformities or defects that can occur in the ear. Auricular defects can vary in size, shape, and location. We can do reconstructive surgery to repair the ear structure to a normal shape ${ }^{4}$. The impact of auricular deformity poses a challenge to the reconstructive surgeon and the patient ${ }^{5}$. One of the most common complications is cartilage exposure following the autologous reconstruction method. The compromise flap is also a complication that occurs after surgery due to flap compromise or infection. In addition, wound healing is a challenge for surgeons to achieve optimal ear shape ${ }^{5,6}$. Various methods are used to accelerate wound healing. Hyperbaric Oxygen Therapy (HBOT) is one of them. This method uses $100 \%$ pure oxygen, which patients can inhale with pressure above 1 atmosphere absolute (ATA) in a chamber ${ }^{7,8}$. Many studies prove that this oxygen therapy provides the maximum effect for accelerating wound healing 9 . This article is a case report that discusses abnormalities in the ear and the effectiveness of hyperbaric oxygen therapy in the mechanism of wound healing.

\section{CASE PRESENTATION}

Case 1

After a violent injury, a 52-year-old man developed an auricular hematoma. Previously, the patient was given a simple aspiration and situational suturing in the auricle by paramedics. After a simple aspiration, the auricular hematoma returned in the form of a cauliflower ear after approximately two weeks (Figure 1A and $1 \mathrm{~B})$
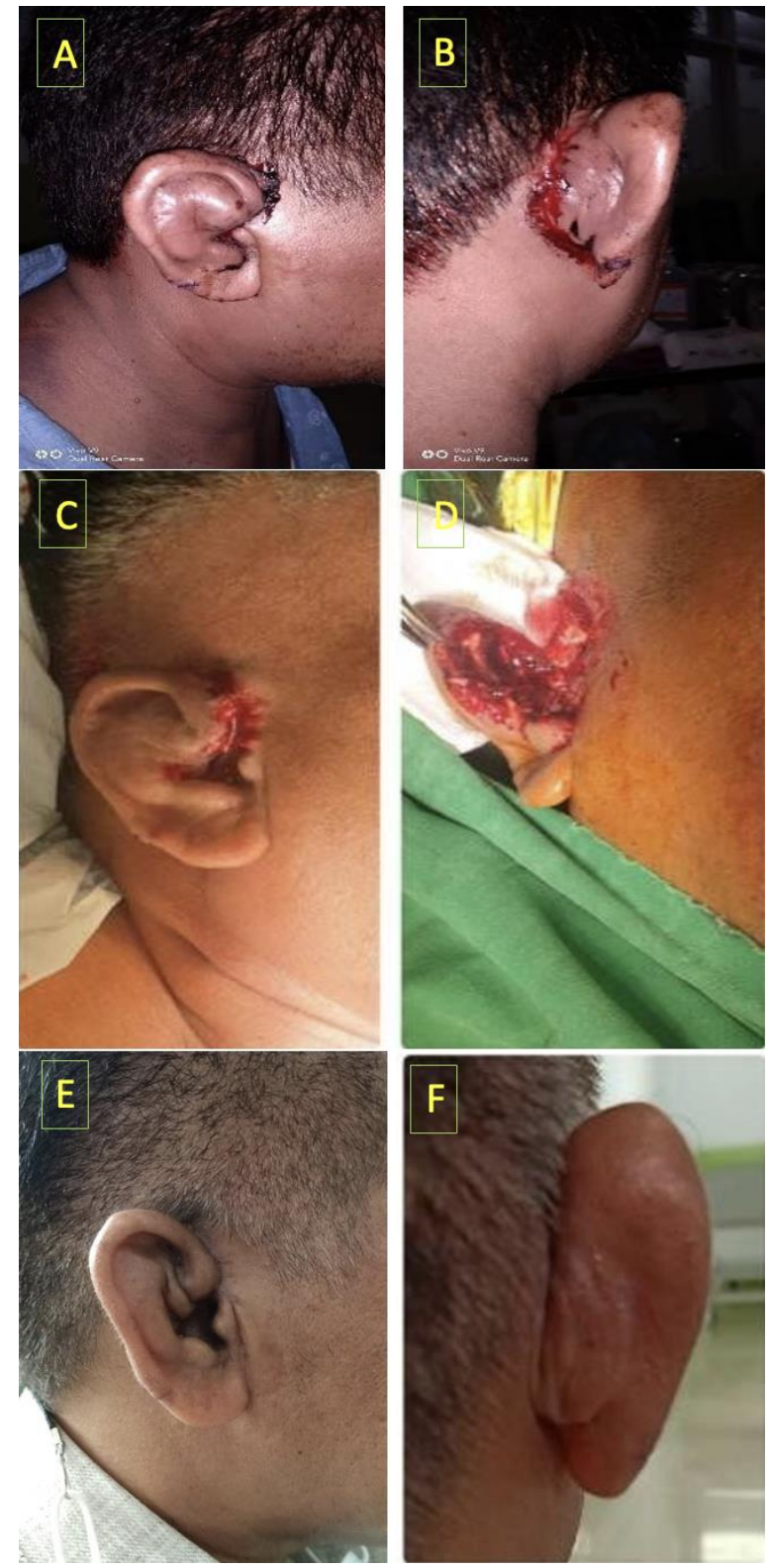

Figure 1. A) A 52-year-old man presented with cauliflower in his right ear due to a traffic accident two weeks before hospital admission. B) Visible of erythema, swelling, slight bleeding, and infection in the right ear. C) Intra-operative, we removed the suture to evacuate the hematoma. D) evacuated some pus and hematoma. E and F) followed-up two months after surgical correction and five times of HBOT. 
We removed the suture, evacuated the hematoma, pus, and re-draping the anterior and posterior skin to the cartilage. We use numerous mattress sutures procedures and tulle as a cushion for one week after surgery. After achieving anaesthesia, the ear was prepped and draped, and we used a No. 15 scalpel blade to make an incision into the hematoma along a natural anatomical crease to allow for the most inconspicuous result. The length of the incision was dictated by the amount of the hematoma, making evacuation easier (Figure 1C and 1D). We used a 4-0 Vicryl or chromic suture to weave through and through the skin and cartilage from posterior to anterior and back anterior to posterior to the degree required to ensure that the ear's contour was regained and that the skin and perichondrium resumed a normal configuration adherent to the cartilage. A row of sutures was occasionally required to establish antihelices folds, retain the helical rim, or allow the superior concha area to have a natural fold into the scapha area. A compression dressing is applied with gauze to fill any void spaces and secure the dressing in place. Antibiotic ointment was then thoroughly applied to both sides of the external ear, and a very loose head covering was used for 12 to 24 hours, mainly for comfort and protection of the ear. After the surgery, the patient is given hyperbaric oxygen therapy in 5 sessions at 2.0 atmospheres absolute (ATA) for 90 minutes per session (Figure 1E and 1F).

\section{Case 2}

A boy 14-year-old has been diagnosed with grade 3 microtia in Marx classification (a small rudiment of soft tissue and no ear canal) (Figure $5 \mathrm{~A})^{10}$. Reconstruction was performed using autologous costochondral cartilage techniques in a two-stage. In stage one, a $2 \mathrm{~cm}$ horizontal incision is designed above contralateral osteochondrosis of ribs 6, 7, and 8. An incision is made anteriorly and removes the existing cartilage. Skin flap made to accommodate the cartilaginous framework. After incision, the perichondrium overlying the synchondrosis of ribs 6,7 , and 8 are sharply divided, and we made carving of auricular framework from rib synchondrosis.

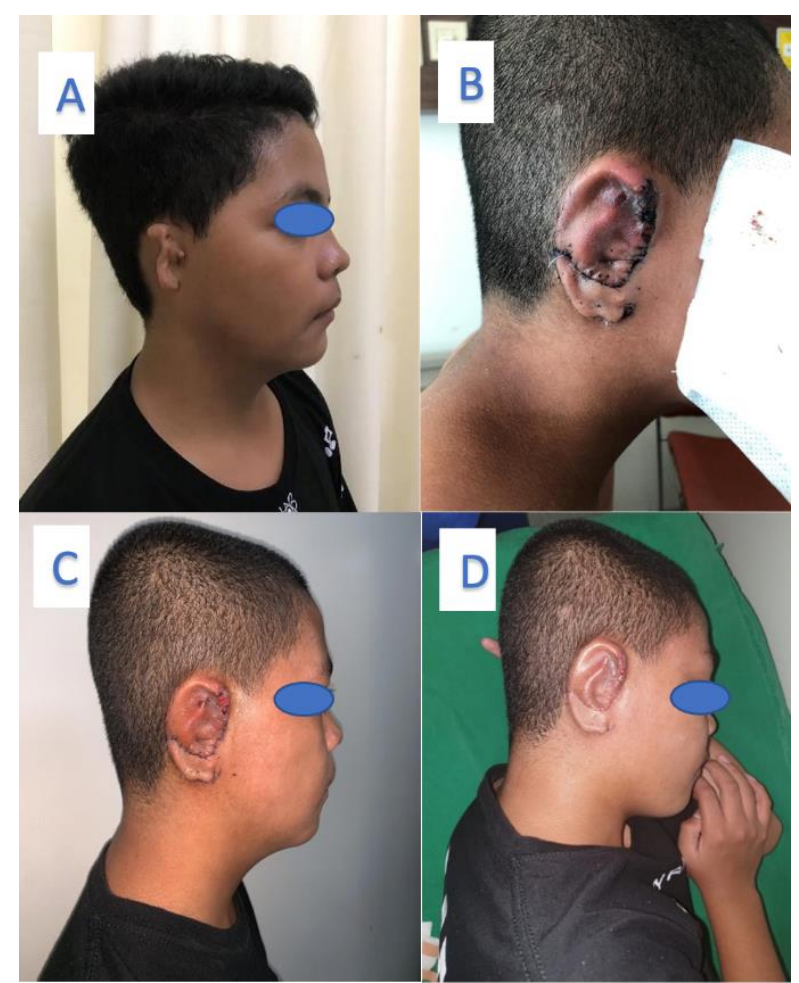

Figure 2. A) Boy 14 years old, with grade three microtia on the right ear. B) Total ear construction using costal cartilage was performed; the third day after surgery, there was a flap compromise with the sign of the flap starting to dark. The patient is immediately given hyperbaric therapy 2.0 ATA for 90 minutes. C) Followed-up after two sessions of HBOT. D) 10 days after the surgery and 5th times of HBOT.

In stage two, incisions are made around the framework, and a postauricular flap is used to cover most of the mastoid cortex. We use three separate skin flaps; the anterior, posterior, and tragus flaps. The wound is closed with a single suction drain and given a dressing on the anterior side, then the patient is directed to sleep on the left side. On the third day after surgery, there was a flap compromise, with the sign of the flap starting to blacken (Figure 5B). The patient continued to be followed up for two days, but the flap was getting darker. The patient was given hyperbaric therapy immediately in 5 sessions at 2.0 atmospheres absolute (ATA) for 90 minutes per session to prevent flap failure.

\section{RESULTS}

In case one, in 5 hyperbaric therapy sessions, there was a significant improvement in wound healing, especially not re-forming to the shape of 
cauliflower ear. Two months after surgery, the entire ear remained viable with no scarring at the surgical site (Figure 4).

For case two, 10 days after surgery and after five sessions of hyperbaric therapy, significant changes in the flap were seen. The flap doesn't blacken; scars improve, there's no cartilage exposed, no signs of infection, and necrosis (Figure 5D).

\section{DISCUSSION}

Auricle bleeding is the accumulation of blood under the perichondrium layer of the auricle. Due to trauma, ear-bleeding is common. The most common causes are wrestling boxers or traffic accidents. When left untreated, the collision can cause infection, cartilage necrosis, and contracture ${ }^{11}$.

Thickening, unusual projection of the anterior ear and, distortion of the auricular outline all are characteristics of the cauliflower ear. A separation of the perichondrium and cartilage occurs when the ear is injured. The perichondral blood vessel tears as a result, and blood accumulates between the perichondrium and cartilage. The hematoma obstructs blood flow, mechanically causes cartilage infection and necrosis ${ }^{12}$. The presence of necrosis around the cartilage will further inhibit the normal ossification process of the cartilage that lives above the defect ${ }^{13}$. Without proper treatment and when new cartilage begins to form in necrotic tissue, it can lead to fibrosis ${ }^{3}$.

The goal of treatment is to remove the hematoma and to prevent re-accumulation of blood. To improve the form of the ears and avoid difficulties, we can use a variety of methods. The method adopted is adjusted according to the degree of damage. For acute and mild auricular bleeding, suction and dressing are usually performed, but sometimes it is unsuccessful when blood coagulation is formed. For more extensive bleeding, surgery and drainage are performed ${ }^{14}$

Usually, the longest treatment time for auricular hematoma is seven days after the trauma. In this case, the patient presented to the doctor two weeks after the accident and developed cauliflower ears with signs of necrosis caused by infection. After the operation and removal of the hematoma, the patient immediately received hyperbaric oxygen therapy. The principle of hyperbaric oxygen is an additional treatment in which the patient is given $100 \%$ oxygen in a chamber with pressure above 1 ATA. Pressure range 1-3 ATA provides benefits to help repair tissue damage ${ }^{15,16}$. The goal is to shorten the inflammatory phase to complete that wound healing before the growth of new cartilage. There are three main benefits of hyperbaric therapy in wound healing. Inflammatory Cell Reduction, Decreased Angiogenesis and Increased Epithelialization. In the case of inflammation, by giving $100 \%$ oxygen, the ability to circulate neutrophils to adhere to target tissues is temporarily inhibited, thereby reducing the level of inflammation ${ }^{17}$.

HBOT reduces the damage caused by ischemia and reperfusion of the flap tissue. HBOT has provided satisfactory results as an auxiliary therapy for auricle reconstruction and has shown a positive effect on the absorption of hematoma and infection prevention ${ }^{18}$.

Microtia is a congenital disorder that results in a smaller or abnormal ear shape. Based on embryology, the outer ear begins to form at the age of the fetus at six weeks and develops into a complete profile at the period of 18 weeks, and will continue to grow until the age of 10 years ${ }^{19,20}$. Microtia may be unilateral or bilateral, and most microtia patients also have aural atresia. Several factors cause microtia, namely genetic disorders and microsomia craniofacial syndrome, that affect the baby's facial development before birth 21

In the case of microtia, reconstruction is the right action to take. Several reconstruction techniques are autologous costochondral cartilage, which is based on the Nagata stage divided into two stages, alloplastic reconstruction, implant reconstruction, and prosthetic reconstruction ear ${ }^{22}$.

The Nagata technique requires collecting a large amount of cartilage for frame design, taken from the scaphoid bone and triangular fossa and then used for carving. In this patient, we drew a horizontal incision line on the lower edge of the upper third. This will approximate the lower edge of the seventh costal cartilage and should be about $2 \mathrm{~cm}$ from the costal edge. The sixth to ninth cartilage is harvested in one piece. Then, from the cartilage of the 6 th and 7 th ribs, a cartilage frame of the auricle is jointly carved out. Then use the cartilage of the 8th rib to create the spiral and spiral lower leg, and use the 9th rib to 
reconstruct the reverse spiral, upper calf, and lower leg23,24. We use three separate skin flaps; the anterior, posterior, and tragus flaps ${ }^{24}$. At this stage, complications persist, such as flap compromise because it involves the simultaneous transfer of flaps and ribs with cartilage transplant, cartilage exposure, and subsequent infection. This is where hyperbaric oxygen therapy is significant to prevent infection and failure at the reconstruction stage.

In several studies, hyperbaric oxygen therapy can increase the flap's survival rate by improving flap blood circulation. In several studies, hyperbaric oxygen therapy can increase the flap's survival rate by improving flap blood circulation ${ }^{18}$. We can preemptively treat many of these wounds with hyperbaric oxygen therapy for the respective problem wound indications to minimize the chance of compromise and improve the likelihood of reconstructive success. Based on our accumulated experience, hyperbaric oxygen therapy can be used to accelerate the recovery of blood supply, shorten the process of follow-up observations, reduce the risk of skin flap necrosis, and relieve the mental burden for both doctors and patients. The success of the combined treatment was mainly attributed to the ability of hyperbaric oxygen therapy to promote the reduction in swelling, accelerate tissue neogenesis, and enhance bactericidal activity.

However, hyperbaric oxygen therapy is an adjunct therapy only, not as primary therapy in both cases. The main therapy for cauliflower ear is evacuating the hematoma, and for microtia cases, it is to save the compromise flap. The administration of hyperbaric oxygen therapy only adds to the presentation of therapeutic success and prevents complications.

\section{SUMMARY}

In accelerating wound healing, reducing infection rates, preventing and improving flap or graft ischemia, hyperbaric oxygen therapy is an option as an adjunct therapy. In our case, Immediate administration of hyperbaric therapy is essential in preventing infection, necrosis, and treated flap compromise. The reconstructions and five sessions at 2.0 ATA for 90 minutes of hyperbaric therapy in each patient showed satisfactory results with the ear back to the normal structure. There is no infection, rapid wound healing, and cessation of flap compromise. This benefit of oxygen therapy is what we use as an adjunct therapy in the case of ear reconstruction. The sooner hyperbaric therapy is given, the better the results. However, our study has limitations regarding the number of cases described and the need for further follow-up.

Correspondence regarding this article should be
addressed to:
Mendy Hatibie Oley
Reconstructive \& Aesthetic Plastic Surgery Division,
Department of Surgery, Faculty of Medicine, University Sam
Ratulangi, Manado, Indonesia
Jalan Raya Tanawangko No.56, Malalayang Satu Barat,
Malalayang, Manado City, North Sulawesi, 95162, Indonesia
E-Mail: mendy.hatibie@unsrat.ac.id

\section{REFERENCES}

1. K. Ali, J.D. Maaike, R.S. Maricevich, A. Olshinka, The Protruding Ear: Cosmetic and Reconstruction, Semin. Plast. Surg. 31 (2017) 152-160. https://doi.org/10.1055/s-00371604241.

2. K. Storck, R. Staudenmaier, M. Buchberger, T. Strenger, K. Kreutzer, A. von Bomhard, T. Stark, Total Reconstruction of the Auricle: Our Experiences on Indications and Recent Techniques, Biomed Res. Int. 2014 (2014) 115. https://doi.org/10.1155/2014/373286.

3. M.D. Gooch, Preventing Cauliflower Ear, Adv. Emerg. Nurs. J. 42 (2020) 204-209. https://doi.org/10.1097/TME.000000000000 0309.

4. R.M. Smith, P.J. Byrne, Reconstruction of the Ear., Facial Plast. Surg. Clin. North Am. 27 (2019) 95-104. https://doi.org/10.1016/j.fsc.2018.08.010

5. I.A. Otto, R.F.M. van Doremalen, F.P.W. Melchels, M.N. Kolodzynski, B. Pouran, J. Malda, M. Kon, C.C. Breugem, Accurate Measurements of the Skin Surface Area of the Healthy Auricle and Skin Deficiency in Microtia Patients, Plast. Reconstr. Surg. Glob. Open. 4 (2016) e1146. https://doi.org/10.1097/GOX.000000000000 1146.

6. P. Ladani, Ear Reconstruction, in: Oral Maxillofac. Surg. Clin., Springer Singapore, Singapore, 2021: pp. 731-745. https://doi.org/10.1007/978-981-15-13466_35.

7. S. Bhutani, G. Vishwanath, Hyperbaric oxygen and wound healing., Indian J. Plast. 
Surg. 45 (2012) 316-24. https://doi.org/10.4103/0970-0358.101309.

8. M.H. Oley, M.C. Oley, A.D. Noersasongko, M. Hatta, G.G. Philips, Agustine, M. Faruk, J.A. Kalangi, I.M.A. Rumampuk, M.T. Tulong, Effects of hyperbaric oxygen therapy on vascular endothelial growth factor protein and mRNA in crush injury patients: A randomized controlled trial study, Int. J. Surg. Open. 29 (2021) 33-39. https://doi.org/10.1016/j.ijso.2021.01.003.

9. S. Opasanon, W. Pongsapich, S. Taweepraditpol, B. Suktitipat, A. Chuangsuwanich, Clinical Effectiveness of Hyperbaric Oxygen Therapy in Complex Wounds, J. Am. Coll. Clin. Wound Spec. 6 (2014) 9-13. https://doi.org/10.1016/j.jccw.2015.03.003.

10. Y. Suzuki, Classification of Shapes (Auricle/ External Auditory Canal), in: 2013: pp. 10-12. https://doi.org/10.1159/000350495.

11. S.E.M. Jones, S. Mahendran, Interventions for acute auricular haematoma., Cochrane Database Syst. Rev. 2004 (2004) CD004166. https://doi.org/10.1002/14651858.CD00416 6.pub2.

12. K. Brickman, D.Z. Adams, P. Akpunonu, S.S. Adams, S.F. Zohn, M. Guinness, Acute Management of Auricular Hematoma, Clin. J. Sport Med. 23 (2013) 321-323. https://doi.org/10.1097/JSM.0b013e31825c4 623.

13. B. Ytrehus, C.S. Carlson, S. Ekman, Etiology and pathogenesis of osteochondrosis, Vet. Pathol. 44 (2007) 429-448. https://doi.org/10.1354/vp.44-4-429.

14. T. Ghanem, J.K. Rasamny, S.S. Park, Rethinking auricular trauma., Laryngoscope. 115 (2005) 1251-1255.

https:// doi.org/10.1097/01.MLG.000016537 7.92622.EF.

15. R. Choudhury, Hypoxia and hyperbaric oxygen therapy: A review, Int. J. Gen. Med. 11 (2018) 431-442. https://doi.org/10.2147/IJGM.S172460.

16. Lam G, Fontaine R, Ross FL, Chiu ES. Hyperbaric Oxygen Therapy: Exploring the Clinical Evidence. Adv Skin Wound Care. 2017 Apr;30(4):181-190. https://doi.org/10.1097/01.ASW.000051308 9.75457.22.

17. M.J. Hatibie, A.A. Islam, M. Hatta, Y. Moenadjat, R.H. Susilo, L. Rendy, Hyperbaric Oxygen Therapy for SecondDegree Burn Healing: An Experimental Study in Rabbits, Adv. Ski. \&amp; Wound Care. 32 (2019) 1-4. https://doi.org/10.1097/01.asw.0000553110. 78375.7b.
18. F. Xu, R. Zhang, Q. Zhang, Z. Xu, D. Li, Y. Li, Hyperbaric Oxygen Therapy: An Effective and Noninvasive Therapy for Complications of Ear Reconstruction., J. Craniofac. Surg. 30 (2019) e382-e385. https://doi.org/10.1097/SCS.0000000000004 969.

19. K. Takano, Hearing Loss in Congenital Microtia, in An Excursus into Hear. Loss, InTech, 2018. https://doi.org/10.5772/intechopen.72429.

20. F. Alasti, G. Van Camp, Genetics of microtia and associated syndromes, J. Med. Genet. 46 (2009) 361-369. https://doi.org/10.1136/jmg.2008.062158.

21. D. V Luquetti, C.L. Heike, A. V Hing, M.L. Cunningham, T.C. Cox, Microtia: epidemiology and genetics., Am. J. Med. Genet. A. 158A (2012) 124-139. https://doi.org/10.1002/ajmg.a.34352.

22. N. Baluch, S. Nagata, C. Park, G.H. Wilkes, J. Reinisch, L. Kasrai, D. Fisher, Auricular reconstruction for microtia: A review of available methods, Plast. Surg. (Oakville, Ont.). 22 (2014) 39-43. https://pubmed.ncbi.nlm.nih.gov/25152646.

23. A. Yamada, Autologous Rib Microtia Construction: Nagata Technique., Facial Plast. Surg. Clin. North Am. 26 (2018) 41-55. https://doi.org/10.1016/j.fsc.2017.09.006

24. T. Shokri, D. White, The Nagata Technique for Microtia Reconstruction, Oper. Tech. Otolaryngol. Neck Surg. 28 (2017). https://doi.org/10.1016/j.otot.2017.03.009. 